\section{Market Demands}

and the Perpetua-

tion of Poverty:

City versus Country

in Jayro Busta-

mante's Ixcanul

Las demandas del mercado y la perpetuación de la pobreza: ciudad vs. campo en Ixcanul, de Jayro Bustamante

Michelle Warren warrenm2@unk.edu

\author{
SONJA H. BICKFORD \\ bickfordsh@unk.edu \\ University of Nebraska
Kearney, USA.
}

SUBMITTED March 21, 2019

ACCEPTED

October 30, 2019

PUBLISHED

January 1 st, 2020

https://doi.org/10.32870/ elojoquepiensa.v0i20.319
A Bstract / In this study, we examine

Ixcanul (2015), a debut film by director Jayro Bustamante. Under a framework of Raymond Williams' landmark study, The Country and the City, we look at how the film portrays a stark contrast between life in the gritty and chaotic Guatemala City and the peaceful and seemingly bucolic coffee plantation where the main characters live, focusing on how the film reveals that the main problems that the indigenous characters experience on that plantation are inextricably tied to the market demands placed on them by the city (and by extension, the consumers from even beyond Guatemala). As the characters navigate between the two worlds (city/country) to deal with their own crises, we see how life on the plantation keeps the Kakchikel characters in a state of perpetual oppression.

KEYWORDS / volcano, Guatemala, kakchikel, Jayro Bustamante, city versus country.
Resumen / En este estudio, examinamos Ixcanul (2015), la primera producción cinematográfica del director Jayro Bustamante. Bajo el marco del estudio fundamental del teorista Raymond Williams (The Country and the City), miramos cómo la película retrata un contraste entre la vida caótica en Ciudad de Guatemala, y la vida aparentemente bucólica en la plantación de café donde viven los personajes principales, enfocándonos en cómo la película revela que los problemas principales que experimentan en la plantación se conectan intrínsecamente con la demanda del mercado creada por la ciudad (y por extensión, con los consumidores más allá de la misma Guatemala). Mientras los personajes navegan entre los dos mundos (ciudad/ campo) para lidiar con sus propios problemas, vemos cómo la vida en la plantación sirve para perpetuar el ciclo de opresión para los kakchikel.

PAlabRas Clave / volcán, Guatemala, Kakchikel, Jayro Bustamante, ciudad vs. campo. 


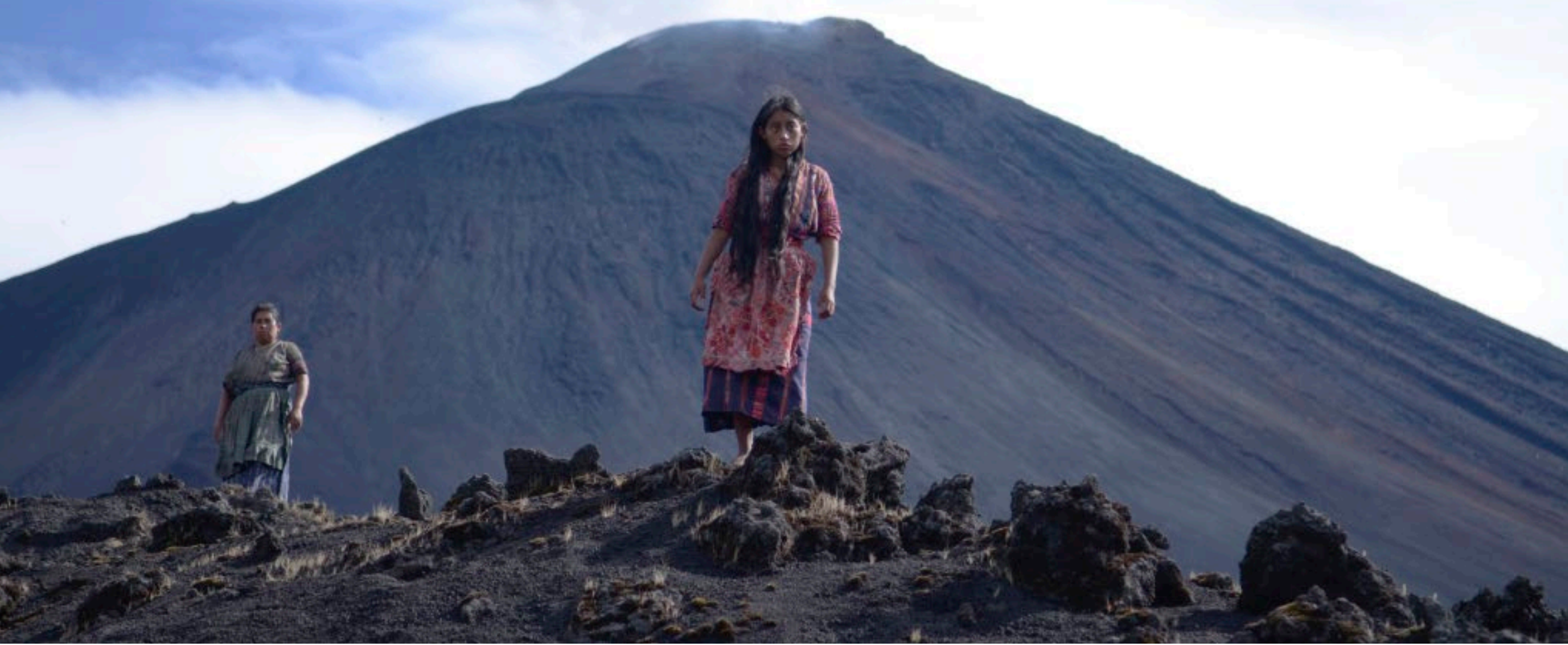

The greed and calculation, so easily isolated and condemned in the city, run back, quite clearly, to the country houses, with the fields and their

labourers around them. And this is a double process. The exploitation of man and of nature, which takes place in the country, is realised and concentrated in the city.

(Williams, 1975)
J

ayro Bustamante, in his 2015 debut film Ixcanul, posits urban life versus life in the countryside to underline the tenuous and deeply entangled relationship between the two in the case of Guatemala. In Ixcanul, we see rural Guatemala contrasted with urban Guatemala, the former characterized by a quiet, lush coffee plantation in the shadow of an omnipresent smoking volcano, and the latter by a chaotic city, where the rural indigenous characters struggle in both linguistic and cultural confusion. Bustamante then overturns the concept of nature as pure and good by showing the imposition of the city and its economic demands on the livelihood of those people who work the plantation, providing coffee for the urban and international markets. In Ixcanul, urban demand and development not only stand in stark negative contrast to the tranquil countryside; they also exert destruction on the countryside through their demands.

As the above-mentioned Williams (1975) quote points out, while the countryside is often portrayed in literature as a locus of peace and tranquility contrasting with urban chaos that peaceful life truthfully never exists as urban demands wreak havoc on it. Ixcanul delivers a view into the starkly different worlds of indigenous, rural 
Guatemala and modern urban Guatemala but also weaves a thread through that rural life showing how, while different than city life, rural life is inextricably bound to and violated by the demands of urban dwellers, and beyond those in Guatemala City, all the way to the international consumers of the coffee and other luxury crops grown on the plantation (Guatemala, n. d.).

Two internationally-known Guatemalan figures, Miguel Ángel Asturias and Rigoberta Menchú, have brought the conditions of Guatemalan indigenous life to the world's attention through their work. Author Miguel Ángel Asturias (18991974) won the Nobel Prize for Literature in 1967. Novels such as his Leyendas de Guatemala (1930) and Hombres de maiz (1949) describe both indigenous culture prior to the arrival of Spaniards, as well as some of the squalid conditions Guatemalan indigenous people suffered into the twentieth century. K'iche' activist Rigoberta Menchú (1959- ) received world-wide recognition with her Nobel Peace Prize in 1992, following the successful reception of her testimonial novel, I, Rigoberta (1983, as told to Elizabeth Burgos). Even thirty some years following the release of that novel, rural and indigenous Guatemalans continue to live in disparaging conditions. The population is around 15.5 million inhabitants, and the country is about the same size as the US state of Pennsylvania. The country's official language is Spanish, which indigenous peoples in rural areas do not speak or understand, speaking instead one of the at least 23 documented indigenous languages accounted for in Guatemala. There is a disproportionately high fertility and growth rate in relation to the rest of Latin America, pronouncedly so in indigenous populations, who have extremely limited access to health care and contraception. Some $80 \%$ of the indigenous population lives in poverty, without electricity and clean drinking water, as the characters in this film (The World Bank, 2018).

The characters in Ixcanul are Kakchikel. In fact, the title itself is a Kakchikel word that means volcano. Ixcanul takes place in rural Guatemala on a coffee plantation in the shadow of the titular volcano. It tells the story of María, a young Kakchikel woman, whose family lives and works there. María is betrothed to Ignacio, the only indigenous character who also speaks fluent Spanish and understands city ways. Ignacio is widowed, and needs María to help him care for his children. Their marriage will also secure a place for María's aging parents once they are no longer able to work, guaranteeing a roof over their head for the rest of their lives. María, however, has other thoughts. She seeks an escape from plantation life and wants to immigrate with a young and misguided plantation worker named Pepe to the USA, or, as Pepe puts it, the "other side of the volcano". It is never clearly evident if María actually loves Pepe, but she very purposefully strategizes a pregnancy with him, thinking that he will then have to take her along to the USA. He leaves without her, and the story of how María, her family, and eventually Ignacio all deal with the pregnancy is what drives the film forward.

The squalid and unjust conditions under which indigenous people in Guatemala live, and one real woman's story in particular, were the impetus for Jayro Bustamante to create this film. In an interview, he tells about meeting the figure who was the inspiration for the film's main character while traveling alongside his mother in rural Guatemala:

It all began when I met María, the real María; a woman from Kakchikel who lives in a very isolated region called Sololá, where there is a great concentration of people of Mayan Kakchikel ethnicity. My mother, who is a doctor, was carrying out medical campaigns to try to convince women to allow their children to be vaccinated against polio, which at the time was ravaging the country. She then met this woman and introduced her to me. She told me her story, I imagined it, and when I met her again, I asked for her permission to tell it to all of you. She said, 'I really want you to share this story because it is the story of many women, not just mine. But I don't want you to share my name, and I don't want to see the film'. She added, 'You did a good thing in telling me, but don't come back to show me'. And there you have it -that is how it all began (Jayro Bustamante Director. Interview, 2015, para. 1). 


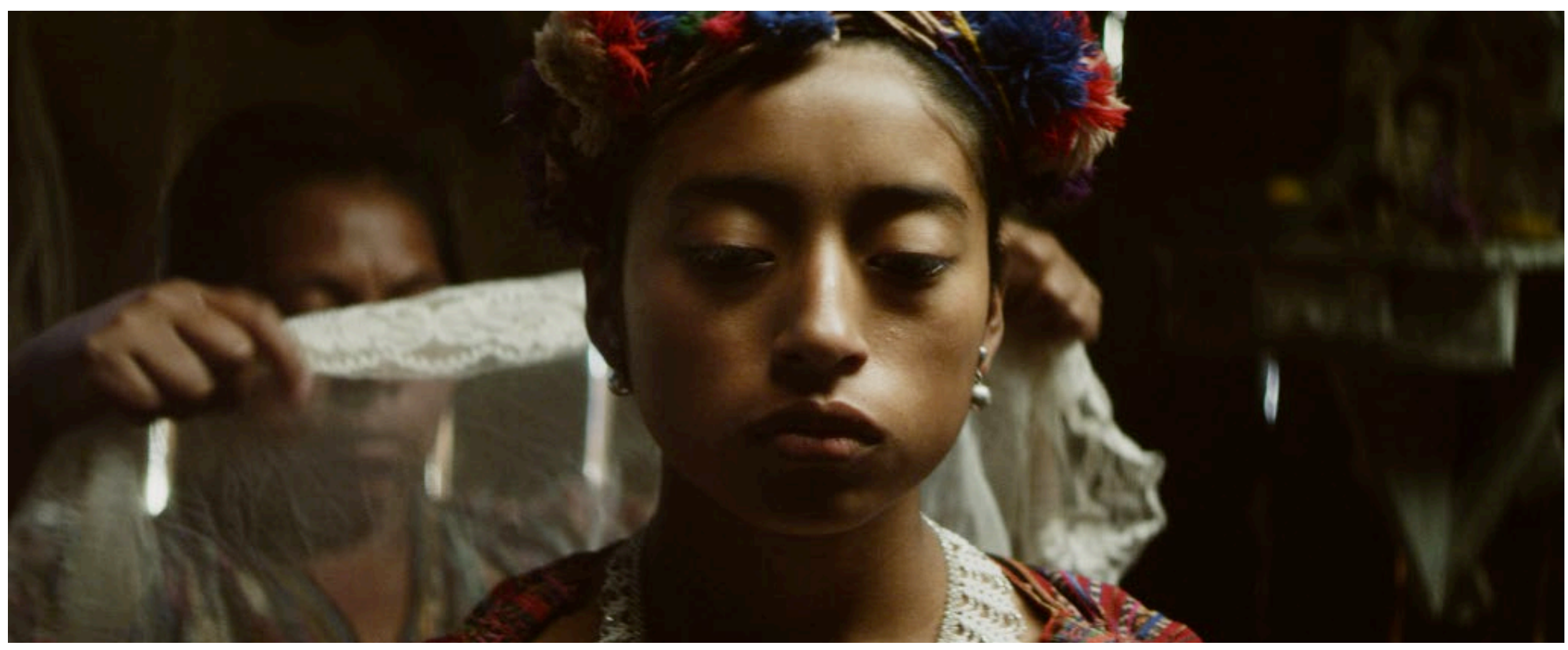

FIGURE 1. Ixcanul (Jayro Bustamante, 2015).

Through Ixcanul, Bustamante reveals the difficult reality in which rural indigenous Guatemalans live. Through his pacing and careful framing of María and her world, Bustamante creates empathy for her vulnerable situation, placing the viewer on her and her family's side of the eventual conflict.

Ixcanul opens and closes in nearly identical scenes: young protagonist María (played by newcomer María Mercedes Coroy) being dressed in traditional celebratory clothing by her mother; in the beginning, to meet her soon-to-be husband, plantation foreman Ignacio; in the end, to actually marry him. The repetition of this scene in the opening and closing of the film (with a few key differences discussed below) suggests a circularity symbolic of the cycle that keeps indigenous Guatemalans in a state of defenseless poverty, victims of Spanish-speakers who keep them ignorant in order to suit their own economic and labor needs [FIGURE 1].

There is a quiet beauty in the lives of seventeen-year-old María and her steady-handed mother, the main two women characters. They lead a seemingly bucolic life, tending to their pigs and chickens, engaging in almost ritualistic bathing and dressing together, and delivering ceremonial offerings to the always-smoking volcano that dominates the background. The natural world María lives in serves as a mentor/teacher for her coming-of-age [FIGURE 2]. She learns of the connection between sexual desire and alcohol as she helps her mother get the pigs drunk on rum so they will mate. She tests out her own sensuality, and how to fulfill herself, as she practices kissing a tree, straddling it and riding it as if it were her lover. Living in close quarters with her parents, María also witnesses their sex life: she is present and feigning sleep in one scene where her mother initiates intimacy. These scenes present the natural world as a lush green natural innocence, unaltered by modern civilization, providing María with a safe sexual experimentation. Eventually, María puts her lessons into action, waiting for a very drunk Pepe outside the local tavern and seducing him.

After María becomes pregnant, we see that all that is countryside is not necessarily pastoral, almost as if her passage into womanhood and losing her virginity invites difficulty into the village and her life. When Pepe and other workers collect their pay from Ignacio, many of them owe almost as much as their wages. Lamentably, a large portion of their salary goes to paying the plantation back for their living expenses, and in Pepe's case, his sizeable bar tab, making it nearly impossible to get ahead financially. Pepe, though seemingly not very wise, does fool his friends into loaning him money and fleeing the plantation to 
travel to the USA. In the process, he also leaves María behind with her unborn child, without an exit strategy, and with a complicated situation she will have to explain to Ignacio.

Here, we begin to observe more collateral damage caused by economic pressure on the land and its workers to produce. We see María and her mother pouring jugs of toxic anti-dengue chemicals into the plantation's water supply. Exposure to these products as well as the ones that are soon introduced to help control an unwanted venomous snake infestation expose María and the rest of the plantation workers to harsh and potentially damaging chemicals. In fact, the snake-killing chemical Ignacio brings from the city (originally from the US, so "it must be good") makes María and her father feel ill from the fumes. María runs off vomiting, and her father confirms that it must be secondary effects from the snake poison; in fact he too feels ill from smelling it.

When the snake-killing product fails to eradicate the plantation of the venomous creatures, the characters turn to traditional belief. Under the guidance of a shaman, who consults the gods and encourages María to use her pregnant state to scare the snakes away, the young mother-to-be attempts such by stomping into the field where the snakes are living. Instead of scaring them, María is bitten on the foot, her life placed in precarious danger. The ensuing race to the city shows the spectators for the first time in the film the dark chaos of the urban center and its effects on the small indigenous community living in the country.

As Ignacio rushes María to the city for medical help, María's mother rides with her in the back of the pickup, holding her in her arms, begging for her survival and repenting for allowing her try to eradicate the snakes [FIGURE 3]. At an hour and several minutes into the otherwise quiet and unrushed film narrative, the cinematography reflects a sudden stylistic change as the characters speed toward the hospital. Film critic Mike D'Angelo notes: "Bustamante accompanies this abrupt shift from the country to the city with an equally abrupt formal shift, going jagged and handheld after nearly an hour of expertly composed shots in dreamy soft focus" (2016, para. 3). Indeed, the tone swings from one extreme to the other. The long, silent languid shots ranging from the opening scene, where María stares unabashedly into the camera as her mother dresses her, to the almost oneiric views of the plantation landscape with the volcano smoking in the background, stand in stark contrast to the scenes where the crisis moment arises and the family hurries toward the city. The slow, leisurely views disappear, and the camera jolts shakily along with Ignacio's pickup as they approach the hospital. The streets are noisy, crowded, and confusing. Traffic screeches around the characters, and Castilian Spanish —which only Ignacio speaksclutters the air. The clamor in the boulevards and inside the hospital reflects what it must feel like for the three non-Spanish speaking characters to be surrounded in a cacophony and chaos of unfamiliar sound, fearing for María's and the unborn baby's lives as the snake venom courses through her body. The confusion ensuing during their time in the hospital allows Ignacio to fool María into signing papers for giving up her baby, convincing her that the child has died but instead selling her off for adoption.

The hospital scene is pivotal in positioning and reinforcing several binary oppositions: country/city, languid/rushed, Kakchikel/Spanish, indigenous/non-indigenous, impotency/ power. Life in the countryside, while not necessarily easy, is depicted cinematographically as tranquilly slow, filled with the resonating clicks of Kakchickel and visually stunning lush vegetation in the foreground of the slow rolling smoke from the volcano. The city and hospital, by contrast, are shown in choppy, jiggling frames, filled with noise and confusion as the indigenous family struggles to make sense of what is happening to María. The final pieces that posit the urban center versus the countryside are the two characters who represent each of those spaces. Ignacio bridges between the urban and the rural, using his Spanish language and cultural fluency, and his self-serving lies to trick María and her parents regarding the 


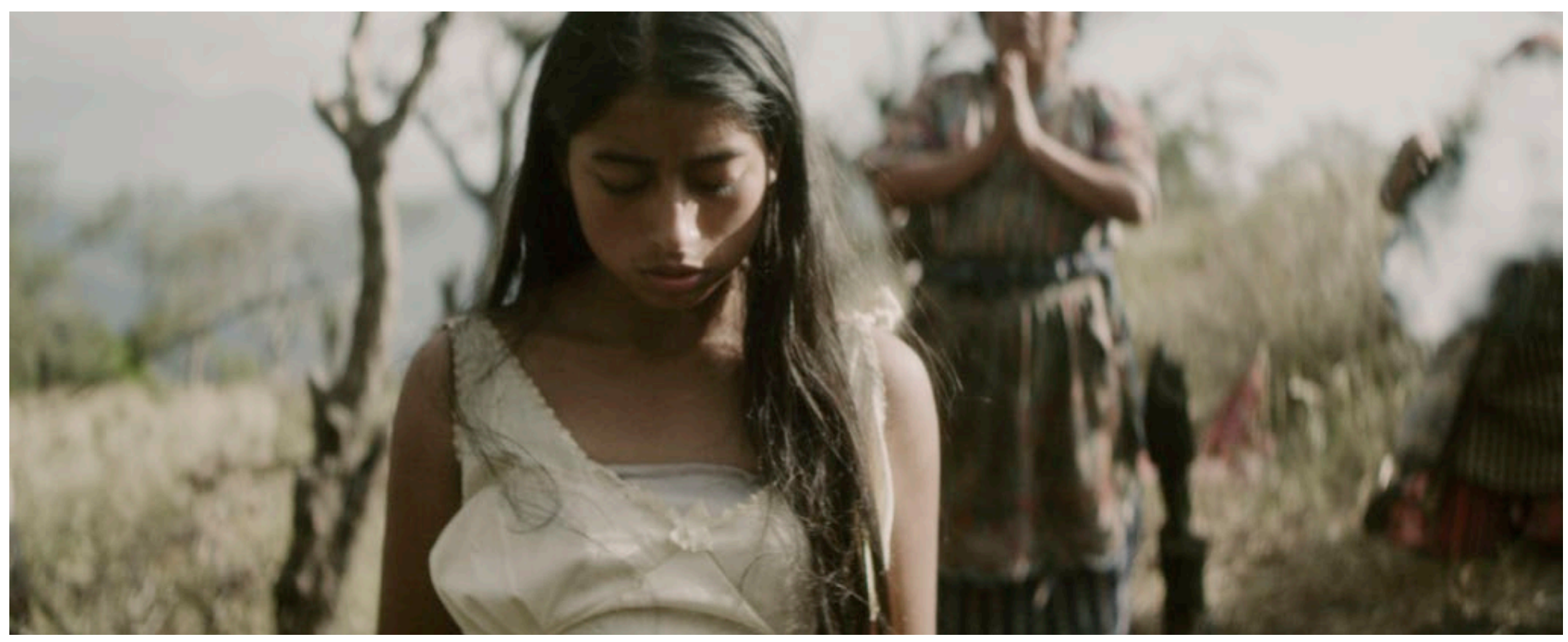

FIGURE 2. Ixcanul (Jayro Bustamante, 2015).

baby's fate. María, by contrast, represents the countryside, violated by the urban demand.

In Williams' The Country and The City, his study of how urban and rural have been juxtaposed in literature throughout history, he dispels the simplified binary opposition of city (bad) and country (good) by showing how the two are necessarily and inextricably intertwined due to supply and demand, as explained in the opening quote of this present study. He notes that people in the country as well as the country itself are exploited because of the demand from urban centers (p. 48). In the countryside of Ixcanul, while the natural world almost appears as its own pristine and innocent entity, we see how demands of the city (both in Guatemala and beyond its borders, where presumably the coffee harvest is destined) invade and infect the countryside.

Both María and Ignacio function in this film as human representations of that cycle of urban imposition on the innocent country, Ignacio straddling the line between country and city, indigenous and fluent in both Spanish and non-indigenous ways, almost turning his status of colonized to colonizer; María innocent like the pristine nature. In fact, María's body is treated like the country fields in that her "crop" (the baby she bears) is harvested from her in the city and sold as a consumable good for a family able to afford it, much like the coffee produced on the plantation and exported to the city to sell. Ignacio, indigenous himself but savvy in the ways of city life and fluent in Spanish, lies to the family, telling them that while María will recover from the snake bite, the baby did not. He encourages María to unwittingly sign adoption papers, convincing her that she is agreeing to receive money from the government for the supposedly dead baby's funeral. This betrayal is key in appealing to the audience members' sympathy toward María and her unsuspecting parents: the implied viewer is privy to Ignacio's machinations and sees how he (and other officials later) trick María and posit her as victim of those (here, Ignacio) who have the power of Spanish language to assert control over the powerless indigenous. Canadian film critic Lydia Ogwang (2015) likens María to a Christian woman martyr in that the theft of her baby is like a decapitation (common for women martyrs): "A removal of property inexorably connected to her body in a violent, flagrant robbery". While we agree that the theft of her baby is indeed a "violent, flagrant robbery", we would also argue that having her baby taken from her body to be sold actually puts María on a parallel with the land her family farms, her "crop", rather than the coffee grown on the plantation, being a live child sold to someone willing to pay 
premium; Ignacio serving again as the intermediary who benefits from the exploitation of her fertility. His character personifies the way that urban demand has violated the bucolic peace of the countryside. Indigenouws himself, Ignacio lives and raises his children among the plantation workers. However, as plantation overseer and the only bilingual indigenous character, Ignacio possesses infinite power over his workers. On several occasions we see Ignacio falsely interpreting conversations between María and her parents and non-Kakchikel speakers.

The final occasion when Ignacio betrays María and her family through his false translation is when they return to the city a final time, supposedly to relocate the baby who had not really died. This second city scene reinforces the opposition of the oppressive, urban versus the more innocent and violated countryside, while also setting up a final commodity: María herself. In the city, María's mother frantically pleads with the officers to help them find the baby, (in Kakchikel), the police officers calmly remind Ignacio (in Spanish) that, should they investigate, María could be arrested for the crime of selling the infant. The officers can see that neither María nor her family could have understood the papers that María "signed" to give up the baby, but rather than addressing the root of the problem (Ignacio, for tricking his indigenous "friends"), they put unsuspecting María in the guilty position of having sold her baby for profit. Upon returning to the plantation without the baby, the final transaction takes place: María's father accepts payment from Ignacio in exchange for forgetting the events surrounding the pregnancy. In paying María's father, Ignacio effectively buys María to be his bride and care for his children. María's father, by accepting the payment, also purchases (with his daughter as payment) a guarantee that he and María's mother will continue to have a place to live as they age. The money presumably goes toward the acquisition of the heavy silver earrings and necklace with which María's mother dresses for her wedding. María (much like the coffee from the plantation and the baby Ignacio sells) is again a commodity; her cooperation, silence, and submission and that of her parents purchased with money from the sale of the baby.

The closing scene, apart from the jewelry María wears, is otherwise identical to the opening of the film. The reiteration in the final shot of María's steady gaze into the camera and her mother dressing her for her nuptials underlines the vicious circle of María's life. Though she tried, she is unable to break the cycle of poverty and servitude dealt to her in the beginning, destined to marry Ignacio, despite her attempts to escape to "the other side of the volcano". The silver jewelry that she dons in this final scene accentuates the money that has exchanged hands throughout Bustamante's film, from the coffee to the sold baby to María herself.

One other principal difference in the final shot is that, unlike in the opening scene, a crumpled, lacy veil enshrouds María's head, eerily erasing her face, denying her previously omnipresent gaze, and rendering her invisible, reinforcing her impotence in determining her own future. Ogwang (2015) purports that the positioning of María's gaze creates a sympathetic bond between her and the spectators. The enshrouding of her face, then, at the end, forces us to see her as invisible or erased, much like her ability to choose her own future.

Although critic Hartman (2017), in his review of the film claims that the film "is just a cold and somewhat brutal look at the encroachment of modern life into a world that has remained relatively untouched by modern advancements", the truth is, Ixcanul reveals the infringement of dominant western culture both discreetly and overtly into the indigenous peoples' lives (poison to kill snakes, language to continue the oppression of non-Spanish speakers, dreams of a prosperous life in USA just beyond the volcano), creating greater disparity between the powerful and the vulnerable (Hartman, 2017). Ixcanul does not offer a finite solution to its problems either, but instead appeals to spectators through the sympathetic characters of María and her parents. Economic exploitation of Guatemala's indigenous peoples for the benefit of US and other non-indigenous, international markets is nothing new, dating 
back to the end of the 19th century with the United Fruit Company and continuing into the present (Zwicklbauer, 2017). Little has changed since the turn of the last century, as indigenous plantation workers continue laboring for next to nothing and existing in impoverished conditions. Bustamante's film provides viewers a highly personalized and relatable depiction of how the market for certain goods (in the case of Ixcanul, coffee and María's baby) abuses and takes advantage of both the countryside and the people who work it.

As Williams (1975) points out in the previously cited study, the countryside is never the peaceful, unscathed place some pastoral literature would make it out to be. Rather, the countryside is always used at the pleasure of the urban (and in this case, also international) market whose demands are supplied by the workers there. In the case of Guatemala, as presented in Ixcanul, we see market demands and managers like Ignacio exercising their dominion over the poor and uneducated indigenous peoples working the plantations. The film's conclusion, by reiterating its beginning, communicates the lack of escape for those trapped in a system that keeps them impoverished and uneducated. Bustamante seeks precisely to open up viewer's eyes to the problematic dynamic between urban/ rural by bringing María's story to the film. María's story, not unique to her but common among other Guatemalan indigenous people, informs the world of the secondary effects of the demand for products created and grown by the hands of people like María and her family, perpetually chained to a life of poverty and servitude, fulfilling market demands of urban Guatemala and beyond that country's borders.

FIGURE 3. Ixcanul (Jayro Bustamante, 2015).

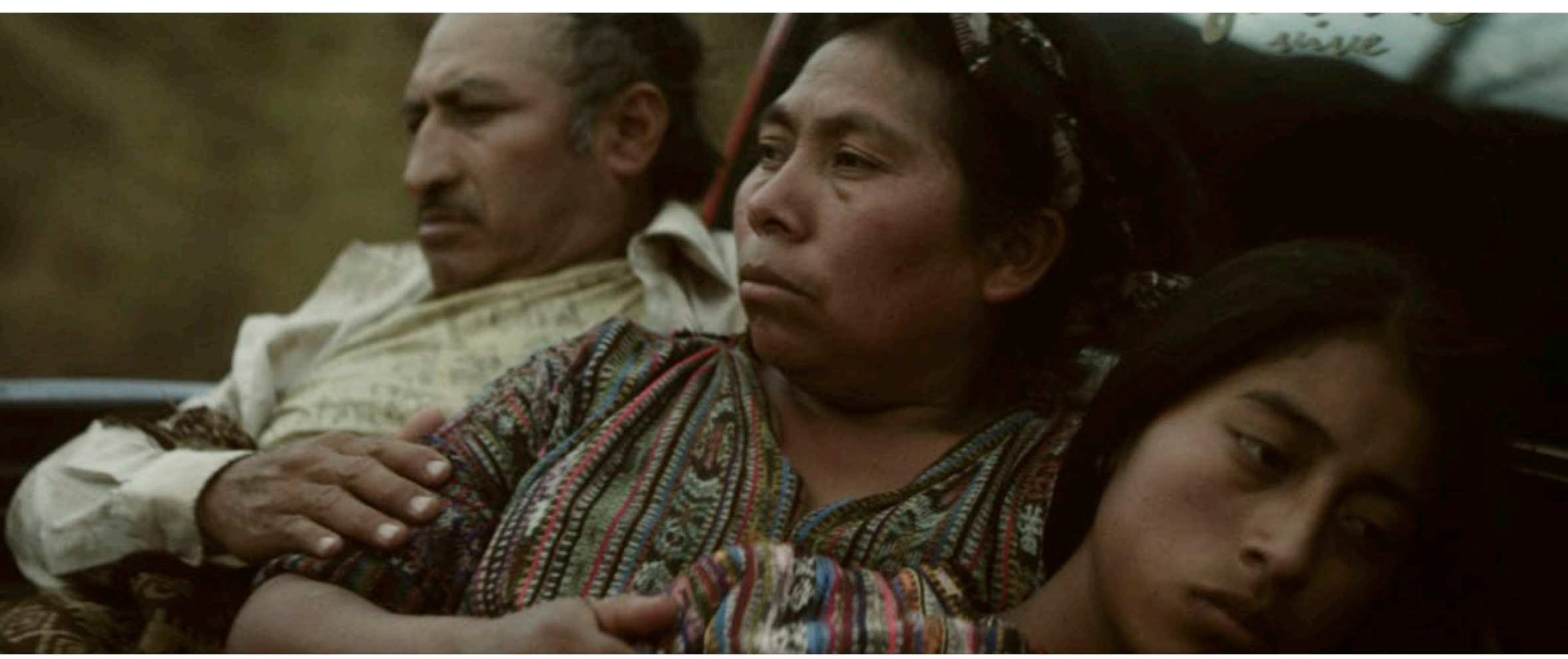




\section{References}

Burgos, E. (2005). Me llamo Rigoberta Menchú y así me nació la conciencia. Mexico City, Mexico: Siglo XXI.

Chaves Espinach, F. (2015, February 21). Jayro Bustamante, director de 'Ixcanul': 'El cine nos permite preguntarnos abiertamente qué está pasando'. La Nación. Retrieved from https:/www.nacion.com/viva/cine/jayro-bustamante-director-de-ixcanul-el-cine-nos-permite-preguntarnos-abiertamente-que-esta-pasando/ AZCBEUL5Q5DX3LNMQ63DZ5FITM/story/

D'Angelo, M. (2016, August 17). Ixcanul is a Debut More Explosive than the Volcano it's Named For. AV Club. Retrieved from https://film.avclub.com/ ixcanul-is-a-debut-more-explosive-than-the-volcano-it-s-1798188595

Guatemala. (n. d.). In Encyclopedia Britannica online. Retrieved from https://www.britannica.com/place/Guatemala/Climate\#ref272497

Hartman, M. (2017, February 2). Ixcanul. Blu-ray High Def Digest. Retrieved from https://bluray.highdefdigest.com/41180/ixcanul.html

Jayro Bustamante Director. Interview. (2015). Cineuropa. Retrieved from http://cineuropa.org/vd.aspx?t=video\&l=en\&did=286435

Ogwang, L. (2015). The Face of Sacrifice. Ixcanul [Blu-ray liner notes].

Shorris, E. and Shoris, S. S. (2005). The Indigenous Literatures of the Americas. Words Without Borders. Retrieved from https://www.wordswithoutborders.org/ article/the-indigenous-literature-of-the-americas

Tedlock, B. (2005). The Woman in the Shaman's Body: Reclaiming the Feminine in Religion and Medicine. New York, NY: Bantam Books.

Tedlock, D. (1986). Popol Vuh: the Mayan Book of the Dawn of Life. New York, NY: Simon and Schuster.

Williams, R. (1975). The Country and the City. Oxford, United Kingdom: Oxford University Press.

The World Bank (2018, October). The World Bank In Guatemala. Overview. Retrieved from http://www.worldbank.org/en/country/guatemala/overview

Zwicklbauer, K. (2017, October 30). Us Democratic Hypocrisy and Economic Exploitation in Guatemala. Virginia Review of Politics. Retrieved from https://virginiapolitics.org/online/2017/10/30/ us-democratic-hypocrisy-and-economic-exploitation-in-guatemala 

E. (Producers). (2015). Ixcanul. Guatemala: Kino Lorber.

Michelle Warren (Ee.Uu.) es Profesora Asociada de Español en la Universidad de Nebraska Kearney. Investiga temas que se relacionan con la identidad étnica, género sexual, y los derechos humanos, así como el teatro, la comedia y el cine. Algunas de sus publicaciones recientes son "Breaking Boundaries: Comedy Curing Stereotypes in Rick Najera's Theatre \& Performance” en Border-Lines y "My Work is More Necessary Than Ever: An Interview with Rick Najera” en Latin American Theatre Review.

Sonja H. Bickford (Ee.uU.) es Profesora Asistente de Comunicación con especialidad en publicidad y mercadotecnia en la Universidad de Nebraska Kearney. Entre sus campos de estudios se encuentran el marketing, el Ártico, la evaluación del impacto de negocios en el medio ambiente, la comunicación, y las artes marciales. Entre sus publicaciones recientes se encuentran "A Comparison of Scholarly Productivity Among Current Professors who Obtained Terminal Degrees" en American Journal of Distance Education, "Communication Processes of Information Technology Executives in Higher Education” en IGI Global, y "Evaluating the Role of CSR and SLO in Ecotourism: Collaboration for Economic and Environmental Sustainability of Arctic Resources” en Resources. 